\title{
SYSTEMATIC REVIEW OF TOPIC TREATMENT FOR VENOUS ULCERS
}

\author{
Eline Lima Borges ${ }^{1}$ \\ Maria Helena Larcher Caliri ${ }^{2}$ \\ Vanderlei José Haas $^{3}$
}

Borges EL, Caliri MHL, Haas VJ. Systematic review of topic treatment for venous ulcers. Rev Latino-am Enfermagem 2007 novembro-dezembro; 15(6):1163-70.

Venous ulcer patients can experience this situation for several years without achieving healing if treatment is inadequate. Evidence-based professional practice generates effective results for patients and services. This research aimed to carry out a systematic review to assess the most effective method to improve venous return and the best topic treatment for these ulcers. Studies were collected in eight databases, using the following descriptors: leg ulcer, venous ulcer and similar terms. The sample consisted of 33 primary studies and two Meta-analyses. A wide range of treatments was identified, grouped in compression therapy (54.3\%) and topical treatment (45.7\%). It was evidenced that compression therapy increases ulcer healing rates and should be used in patients with intact arteries. There is no consensus about the best topical treatment, although different options should be associated with compression therapy.

DESCRIPTORS: varicose ulcer; evidence-based medicine; review literature

\section{REVISIÓN SISTEMÁTICA DEL TRATAMIENTO TÓPICO DE LA ÚLCERA VENOSA}

Pacientes con úlcera venosa pueden convivir con esta situación durante varios años, sin obtener la cicatrización de la herida caso el tratamiento no sea adecuado. La práctica profesional basada en evidencias produce resultados efectivos para el paciente y para los servicios. La finalidad del estudio fue realizar una revisión sistemática para evaluar el método más eficaz para mejorar el retorno venoso y el mejor tratamiento tópico de la úlcera. Se buscaron estudios indexados en ocho bases de datos, mediante los descriptores úlcera de pierna, úlcera venosa y similares. La muestra incluyó 33 estudios primarios y 2 estudios de metanálisis. Se identificó una diversidad de tratamientos que fueron agrupados en terapia compresiva (54,3\%) y tratamiento tópico $(45,7 \%)$. Fue evidenciado que la terapia compresiva aumenta la tasa de cicatrización de la úlcera y que debe ser usado en pacientes sin comprometimiento arterial. No queda claro cual es la mejor terapia tópica. Sin embargo, las diferentes opciones deben ser asociadas a la terapia compresiva.

DESCRIPTORES: úlcera varicosa; medicina basada en evidencia; literatura de revisión

\section{REVISÃO SISTEMÁTICA DO TRATAMENTO TÓPICO DA ÚLCERA VENOSA}

Pacientes com úlcera venosa podem conviver com essa situação durante vários anos, sem obter a cicatrização da lesão se o tratamento não for adequado. A prática profissional, baseada em evidências, produz resultados efetivos para o paciente e para os serviços. O estudo visou realizar revisão sistemática para avaliar o método mais eficaz para melhorar o retorno venoso e o melhor tratamento tópico da úlcera. Buscou-se estudos indexados em oito bases de dados utilizando-se os descritores úlcera de perna, úlcera venosa e similares. A amostra constituiuse de 33 estudos primários e 2 estudos de metanálise. Identificou-se diversidade de tratamentos que foram agrupados em terapia compressiva (54,3\%) e tratamento tópico (45,7\%). Evidenciou-se que a terapia compressiva aumenta a taxa de cicatrização da úlcera devendo ser usado em pacientes sem comprometimento arterial. Não é claro qual a melhor terapia tópica, porém, as diferentes opções devem ser associadas à terapia compressiva.

DESCRITORES: ulcera varicosa; medicina baseada em evidências; literatura de revisão

${ }^{1}$ RN, PhD in Nursing, Professor, Minas Gerais Federal University, College of Nursing, Brazil, e-mail: eborges@ufmg.br; ${ }^{2}$ RN, Free-Lecturer Professor, e-mail: mhcaliri@eerp.usp.br; ${ }^{3} \mathrm{PhD}$ in Sciences, Professor, e-mail: haas@eerp.usp.br. University of São Paulo at Ribeirão Preto, College of Nursing, WHO Collaborating Center for Nursing Research Development, Brazil 


\section{INTRODUCTION}

Leg ulcers can be caused by several factors, such as vascular, metabolic and hematological alterations, while the main cause in industrialized countries is chronic venous insufficiency, with the consequent appearance of venous leg ulcers ${ }^{(1)}$.

The physiopathologic disorder determines venous hypertension, secondary varices, edema and trophic changes, whose ultimate expression is the ulcer, which represents approximately $70 \%$ to $90 \%$ of the total of leg ulcers ${ }^{(1-2)}$.

Although it is difficult to determine the exact number of leg ulcers in the North American population over 65, an increase is estimated from $12 \%$ in 1988 to around $22 \%$ in 2030 . The incidence of chronic venous insufficiency is approximately $5.9 \%$ and the prevalence of venous ulcers is around $1 \%$ in the Western world, and more frequent in the elderly ${ }^{(3)}$. The study performed in Harrow, United Kingdom, identified a global prevalence of leg ulcers of $0.18 \%$, while $38 \%$ presented evidence of deep venous system incompetence, $43 \%$ superficial venous system, $31 \%$ presented signs of ischemia and only $10 \%$ did not show signs of arterial or venous insufficiency ${ }^{(4)}$.

There are few studies on the prevalence or incidence of leg ulcers in Brazil. One of the them was performed in Botucatu, SP, Brazil and its prevalence was approximately $1.5 \%$ of cases of venous active or healed ulcers ${ }^{(5)}$.

It is observed, in health service practice, that the patient with venous ulcer is frequently attended for medical consultations, dressing changes with successive changes in topical treatment and sometimes, without association of any compression therapy. Sometimes, patients live this situation during many years without achieving healing. Currently, the need for evidence-based professional practices in order to produce effective results for patients and services is highlighted. However, health professionals still find it difficult to implement evidencebased practice. It is appointed that the use of this reference framework to support practice requires the availability of research results that offer strong evidence, which is not the case in this area in most countries. The use of systematic reviews can help to revert this situation because it aims to reduce a great variety of available research results, translating them in recommendations, allowing professionals to keep up to date, in addition to supporting the choice of interventions ${ }^{(6)}$.

\section{OBJECTIVE}

This research aimed to perform a systematic review of primary studies and meta-analysis on topical treatment of leg venous ulcers, aiming to answer a set of questions presented in clinical practice, including: 1. Which is the most effective method to improve venous return?

2. What are the topical treatments recommended for venous ulcers?

\section{METHODS}

Search strategy for identification of studies

The bibliographic search was carried out in publications indexed or catalogued in PUBMED, DEDALUS, BDENF, LILACS, CINAHL, COCHRANE, National Guideline Clearing House - (NGC) and Sigma Theta Tau International Registry of Nursing Research. Inverse search was also used, which is a method to select documents based on the bibliography of primary documents recovered in the previous search ${ }^{(6)}$.

The following descriptors or key words were used for the bibliographic search: leg ulcer/ venous ulcer/ stasis ulcer/ varicose ulcer and similar terms in Portuguese and Spanish. The search delimitation considered the term topical treatment. The search was performed between March and June 2003 and the first selection of the articles was made through the analysis of abstracts.

National libraries' bibliographic commuting service was used for locating publications, in addition to CAPES Journal Portal, the search engine Google and private collections of researchers in the theme area. To select the publications, the following criteria were considered: focus on human beings; Portuguese, Spanish and English; period of publication from 1993 to 2003 and the limit to locate the publication in Brazil was October 2003.

Criteria for selecting studies for review

- Subjects

Only studies were included whose sample was composed of adult and elderly subjects with venous ulcer or described as stasis or varicose ulcer, except for arterial, mixed, diabetic etiology or purpura, schoenlein-Henoch.

- Intervention

Studies were included which evaluated treatments aimed at the improvement of venous return, such as compression hosiery or bandaging, as well as topical treatment with occlusion of the damaged area. Studies on topical treatment not commercially available in Brazil, such as the use of growth factors and cell culture, or studies whose results were not declared or explicit in the publication, were excluded. 
- Results or measured outcomes

The following dependent variables were considered measures to evaluate efficacy: reduction of the damaged area $\left(\mathrm{cm}^{2}\right)$, healing rate, average time of coverage duration, number of bacteria in the lesion, relapse, reduction of ankle circumference, level of pressure provided by the compression therapy.

\section{- Study Design}

Studies of various designs were selected, classified according to the level of evidence proposed by Stetler and collaborators ${ }^{(7)}$ : level I - meta-analysis of controlled multiple studies; level II - individual experimental study; level III - quasi-experimental, controlled and non-random study - pre and post test; level IV - non-experimental study, as well as descriptive correlational and qualitative research, or case study; level $\mathrm{V}$ - case report or systematically obtained data, whose quality can be verified, or data from evaluation programs. Opinion articles by respected authorities or expert committee opinions, classified as level VI, were not considered.

Review methods

To systematize the analysis of the quality of primary studies, an instrument based on methodological guidelines was created ${ }^{(8-9)}$. Data were collected regarding the journal (title, language, date of publication), author (nationality, education, work place) and study (research funds, type of study, objective, sample characteristics, design, intervention, variables, analysis, results, according to elected outcomes, limitations and recommendations). For the critical evaluation of secondary studies (systematic reviews), besides data about the journal, author and study, the articles were classified into descriptive analysis or meta-analysis, according to the type of synthesis used in the data analysis ${ }^{(10)}$.

The critical evaluation process consisted in reading and evaluating the studies, and then filling out the data collection instruments. Around $50 \%$ of the selected studies were analyzed by the second author to validate the process, with a view to the concordance level. Any discordance was resolved with discussions. Studies published twice or found in more than one database were considered only once.

For data analysis, after appropriate codification of each study's variables, double digitation was used for the validation process. Once validated, data were exported to and analyzed in the Statistical Package for the Social Science (SPSS) program. The results of each selected study were synthesized and, next, a qualitative systematic review was carried out, since the studies differed in terms of design, research question and form of performing the intervention and measuring the outcome.

\section{RESULTS}

\section{Study Characterization}

The sample was composed of 33 primary studies and two meta-analyses, totaling 35 . The studies addressed a diversity of topical treatments for venous ulcer. Nineteen $(54.3 \%)$ referred to compression therapy and $16(45.7 \%)$ were related to topical therapy (Table 1 ).

Table 1 - Type of treatment and design of the studies analyzed. Ribeirão Preto, 2005

\begin{tabular}{|c|c|c|c|c|c|c|c|c|c|c|c|c|}
\hline \multirow{3}{*}{ Type of Treatment } & \multirow{2}{*}{\multicolumn{2}{|c|}{$\begin{array}{l}\text { Experimental w/ } \\
\text { randomization }\end{array}$}} & \multicolumn{6}{|c|}{ Design } & \multirow{2}{*}{\multicolumn{2}{|c|}{ Case Report }} & \multirow{2}{*}{\multicolumn{2}{|c|}{ Total }} \\
\hline & & & \multicolumn{2}{|c|}{$\begin{array}{c}\text { Quasi } \\
\text { experimental }\end{array}$} & \multicolumn{2}{|c|}{ Metananalysis } & \multicolumn{2}{|c|}{$\begin{array}{l}\text { Descriptive } \\
\text { Exploratory }\end{array}$} & & & & \\
\hline & $\mathbf{n}$ & $\%$ & $\mathbf{n}$ & $\%$ & $\mathbf{n}$ & $\%$ & $\mathrm{n}$ & $\%$ & $\mathbf{n}$ & $\%$ & $\mathbf{n}$ & $\%$ \\
\hline \multicolumn{13}{|l|}{ Compression Therapy } \\
\hline Bandage 4 layers & 1 & 5.3 & 1 & 14.3 & 0 & .0 & 4 & 100.0 & 0 & .0 & 6 & 17.1 \\
\hline Bandage short extension & 1 & 5.3 & 1 & 14.3 & 0 & .0 & 0 & .0 & 1 & 33.3 & 3 & 8.6 \\
\hline Pneumatic Compression & 1 & 5.3 & 1 & 14.3 & 0 & .0 & 0 & .0 & 1 & 33.3 & 3 & 8.8 \\
\hline Unna's boot & 2 & 10.5 & 0 & .0 & 0 & .0 & 0 & .0 & 0 & .0 & 2 & 5.7 \\
\hline Three-layer bandage & 1 & 5.3 & 0 & .0 & 0 & .0 & 0 & .0 & 0 & .0 & 1 & 2.9 \\
\hline General Compression Therapy & 0 & .0 & 0 & .0 & 1 & 50.0 & 0 & .0 & 0 & .0 & 1 & 2.9 \\
\hline Radiant heat bandage & 0 & .0 & 1 & 14.3 & 0 & .0 & 0 & .0 & 0 & .0 & 1 & 2.9 \\
\hline High and Medium compression hosiery & 0 & .0 & 0 & .0 & 1 & 50.0 & 0 & .0 & 0 & .0 & 1 & 2.9 \\
\hline Medium compression hosiery & 0 & .0 & 1 & 14.3 & 0 & .0 & 0 & .0 & 0 & .0 & 1 & 2.9 \\
\hline \multicolumn{13}{|l|}{ Topical Treatment } \\
\hline Hydrocolloid & 4 & 21.1 & 0 & .0 & 0 & .0 & 0 & .0 & 1 & 33.3 & 5 & 14.3 \\
\hline Essaven gel & 2 & 10.5 & 1 & 14.3 & 0 & .0 & 0 & .0 & 0 & .0 & 3 & 8.6 \\
\hline Hydrofibrer & 2 & 10.5 & 0 & .0 & 0 & .0 & 0 & .0 & 0 & .0 & 2 & 5.7 \\
\hline Mupirocine ointment & 1 & 5.3 & 0 & .0 & 0 & .0 & 0 & .0 & 0 & .0 & 1 & 2.9 \\
\hline Polyurethane foam & 1 & 5.3 & 0 & .0 & 0 & .0 & 0 & .0 & 0 & .0 & 1 & 2.9 \\
\hline Ultrasound & 1 & 5.3 & 0 & .0 & 0 & .0 & 0 & .0 & 0 & .0 & 1 & 2.9 \\
\hline Laser & 1 & 5.3 & 0 & .0 & 0 & .0 & 0 & .0 & 0 & .0 & 1 & 2.9 \\
\hline Anti-septic & 0 & .0 & 1 & 14.3 & 0 & .0 & 0 & .0 & 0 & .0 & 1 & 2.9 \\
\hline Silver Sulfadiazine & 1 & 5.3 & 0 & .0 & 0 & .0 & 0 & .0 & 0 & .0 & 1 & 2.9 \\
\hline Total & 19 & 100.0 & 7 & 100.0 & 2 & 100.0 & 4 & 100.0 & 3 & 100.0 & 35 & 100.0 \\
\hline
\end{tabular}


From the total of studies, six (17.1\%) were about the use of the four-layer bandage system. However, studies on other forms of compressive therapy were also found, three $(8.6 \%)$ of which were on short extension bandage, three ( $8.6 \%)$ on pneumatic compression and two $(5.7 \%)$ on the use of the Unna boot.

Regarding studies on topical therapy, five $(14.3 \%)$ addressed the use of hydrocolloid, three ( $8.6 \%)$ Essaven gel, two (5.7\%) on hydrofiber and six $(17.1 \%)$ discussed several treatments.

Regarding the research design, the majority of studies were experimental with randomization $(54.3 \%)$, followed by quasi-experimental studies (20\%). Only two studies were meta-analyses (5.7\%). Considering the design and type of treatment, from the 19 experimental studies, six $(31.58 \%)$ were about compression therapy and 13 (68.42\%) about topical therapy. Four (21.1\%) studies were on hydrocolloid, two (10.5\%) on hydrofiber, two (10.5\%) on Essaven gel and two (10.5\%) on the Unna boot. In the quasi-experimental design group, seven studies were found, five of which referred to compression therapy and two to topical therapy. In the descriptive exploratory category, all four studies discussed treatment with the four-layer bandage system. As to case reports, two addressed treatment with short extension bandage or pneumatic compression and one the use of hydrocolloid.

The two metanalyses were related to compressive therapy. One of them, with a sample of 22 studies, evaluated the effectiveness and costeffectiveness of compression bandage and hosiery in ulcer treatment ${ }^{(11)}$. The other, with a sample of two studies, evaluated the effect of compression bandage in relapse prevention ${ }^{(12)}$.

The category of studies on compression therapy also included six randomized clinical studies. The number of patients in these studies varied from 22 to 80 . The studies compared several compression therapies, such as: long extension compression bandages compared to short extension compression bandages(13); Unna boot associated to intermittent pneumatic compression to Unna boot only ${ }^{(14)}$; fourlayer compression bandage to short extension compression bandage ${ }^{(15)}$; Charing Cross four-layer compression bandages to an alternative compression bandage with a three-layer system ${ }^{(16)}$; Unna boot with minimally invasive surgery ${ }^{(17)}$ and Unna boot and compression bandage ${ }^{(18)}$. The main outcomes evaluated were ulcer healing rate (four studies) and the level of compression offered by the bandage (one study).

In the five quasi-experimental studies on compressive therapy, the number of participants varied from 17 to 44 in four, while one study considered the number of patient legs $(n=42)$ as a sample. These studies compared intermittent pneumatic compression, provided by $30^{\prime}$ and $60^{\prime(19)}$, application or not of radiant heat ${ }^{(20)}$, elastic compression bandage, long extension with inelastic compression, short extension with fourlayer compression ${ }^{(21)}$, two alternative systems of multilayer compression $^{(22)}$ and comparison of three types of compression hosiery class II, with 25 to $35 \mathrm{mmHg}^{(23)}$. As the main outcome, they evaluated the level of compression provided by the bandage or hosiery, healing rate, skin blood flow at rest, venous volume and capillary refill time and reduction of damaged area.

The four studies on compressive therapy with a descriptive-exploratory design proposed to: evaluate the relation between the pattern of venous incompetence and wound healing in patients using fourlayer compression bandages ${ }^{(24)}$; determine the healing rate and cost of compression therapy ${ }^{(25)}$; determine the healing rate with the use of the four-layer compression bandage system, Charing $\operatorname{Cross}^{(26)}$ and evaluate the efficacy of the four-layer bandage system, Parema ${ }^{(27)}$. The study samples varied from 50 to 438 subjects and one counted 198 legs as a sample.

Among the case reports, one described two cases of intermittent pneumatic compression ${ }^{(28)}$ and the other the use of short extension bandage ${ }^{(29)}$.

One of the studies that addressed the topical therapy of venous ulcer was a case report and 15 were prospective controlled clinical trials. Two of these were quasi-experimental studies. The study samples were composed by venous ulcers or by the patients with venous ulcer.

Treatments were diversified and compared: hydrofiber dressing with calcium alginate ${ }^{(30)}$; nonadhesive polyurethane with hydrocolloid, both associated to high compression bandage ${ }^{(33)}$; hydrocolloid with gauze, both associated to Unna's boot $^{(34)}$; hydrofiber with calcium alginate, both associated to class C3 compression bandage ${ }^{(35)}$; application of ultrasound with placebo, both associated to hydrocolloid ${ }^{(36)}$; topical treatment associated to laser stimulation compared with topical treatment associated to placebo, compared with topical treatment only ${ }^{(37)}$; cryopreserved cultured epidermal graft with 
hydrocolloid dressing(38); growth factor with silver sulfadiazine and with placebo ${ }^{(39)}$; two studies of essaven gel with placebo ${ }^{(40-41)}$; mupirocine with vehicle ${ }^{(42)}$.

The two non-randomized studies compared essaven gel with placebo ${ }^{(43)}$ and the association of hydrocolloid with PVP-I ${ }^{(44)}$. The case study was a pilot study evaluating the properties of the hydrocolloid ${ }^{(45)}$.

Level of evidence

The majority of the studies analyzed (54.3\%) showed evidence of level II and a minority (5.7\%) level I.

Regarding the type of treatment, among the two studies of level I, one addressed compression therapy in general and the other the use of medium and high compression hosiery. Of the 19 studies of level II evidence, four (21.1\%) were about the treatment with hydrocolloid and two on each theme: hydrofiber, essaven gel and Unna's boot.

Assessed outcomes

In $22(62.9 \%)$ studies, the authors did not declare the primary outcome (main dependent variable) and considered two or more outcomes. The most frequent outcomes evaluated were the reduction of damaged area and healing rate. From 19 experimental randomized studies, four $(21.1 \%)$ presented the primary outcome, while the other 15 (78.9\%) presented three or more outcomes. Among the quasi-experimental studies, only one $(14.3 \%)$ presented one outcome, while five $(71.5 \%)$ presented two or three outcomes.

Sample size determination/clinical and statistical relevance

Information regarding sample size determination was not given in the majority $(77.1 \%)$ of studies and, in five (14.3\%) of them this information did not apply due to the design type, like in the metaanalyses and case reports. Thus, from the 35 studies, only eight presented statistically significant results and only two (25.0\%) described the sample size determination. Two (25.0\%) studies were on treatment with hydrofiber and the remaining were on other topical therapies like mupirocin ointment, hydrocolloid, ultrasound application, compression therapy, Unna's boot and pneumatic compression corresponding to one $(12.5 \%)$ study each.

\section{DISCUSSION}

Aiming for venous ulcer healing, the treatment for improving venous return must be delivered by physicians, nurses and other health professionals with the patient's cooperation and the use of compression therapy is essential, since it increases the healing rate of venous ulcers, when compared to the treatment without compression ${ }^{(11)}$. The compression therapy must be consistently applied in order improve the care effectiveness and reduce treatment cost ${ }^{(11,24)}$. Professionals who use the system must be trained ${ }^{(15)}$, since inadequate application of compression can lead to complications.

Graduated compression can control or reduce venous insufficiency ${ }^{(1)}$, though it must be used to heal non-complicated venous ulcers ${ }^{(11,25)}$, that is, patients who present an ankle/arm pressure index $\geq 0.8^{(15)}$. There are situations in which graduated compression is counter-indicated, like in moderated and severe blood insufficiency, carcinoma, as well as in patients who are developing deep venous thrombosis ${ }^{(1)}$.

A better healing rate was obtained with the use of high compression bandage $(40 \mathrm{mmHg})$ instead of low compression or non-elastic compression bandages ${ }^{(11)}$. The graduated high compression with a multilayer system capable of sustaining compression $(40 \mathrm{mmHg})$ must be used at least once a week $^{(11)}$ as the first choice treatment for non-complicated venous ulcers. So far, when compared with other multilayer compression bandage systems, using the same compression levels, the original four-layer Charing Cross compression system did not present differences in benefits like healing rate, comfort and time of permanence ${ }^{(11,15-16,27)}$.

Some studies presented similar healing rates of venous ulcers using four-layer and short extension bandages ${ }^{(11,20-21)}$, considering that the latter needs external support of one retention layer, such as the self adherent bandage, which can cause complications in members with extreme dimensions ${ }^{(21,28)}$. Other studies demonstrated better rates with the four-layer bandages when compared to Unna's paste associated to self-adherent bandage ${ }^{(11)}$.

Regarding intermittent pneumatic compression, results suggest that it favors the treatment of venous ulcer and must be considered as adjunct therapy. However, this recommendation is not a consensus, since its use did not produce differences in all analyzed studies ${ }^{(28)}$. 
The use of radiant heat bandage shows to be safe and efficient for hospitalized patients with recalcitrant venous ulcer, but it requires more evaluations in order to investigate its efficacy in outpatient treatment ${ }^{(19)}$.

There were no evidences indicating the best topical therapy. The study results suggest the use of a simple, non-adherent coverage, of low cost and acceptable by patients. Polyurethane foam, hydrocolloid and calcium alginate are presented as treatment options $^{(30-35)}$. Hydrofiber or calcium alginate dressings must be used in intensively exudative $(29,34)$ venous ulcers and polyurethane foam or hydrocolloid in ulcers with a low to moderate volume of exudate ${ }^{(30-32)}$.

In case hydrocolloid coverage is used in association with zinc oxide paste (Unna's boot), at the end, a gradient compression bandage should be applied $^{(34)}$

In summary, dressings must be associated to compressive therapy in venous ulcer treatment. It is affirmed that a reduction of more than $30 \%$ in the wound area in the first two weeks of treatment is a prediction of healing ${ }^{(34)}$.

Patients with extensive ulcer or associated to arterial commitment can be favored with adjunct healing techniques, such as human skin and arterial revascularization, when possible ${ }^{(25)}$. Minimally invasive surgical procedures are suggested for patients with primary commitment of the superficial venous system ${ }^{(17)}$.

The use of elastic compression hosieries (35 to $45 \mathrm{mmHg})^{(23)}$, both of high (45 to $50 \mathrm{mmHg}$ ) and moderate ( 30 to $40 \mathrm{mmHg}$ ) compression ${ }^{(12)}$, is recommended to reduce ulcer relapse rates.

\section{CONCLUSION}

The results suggest that compression treatment increases the healing rate of venous ulcers when compared to treatment without compression and results in reliable and cost effective healing in the majority of patients. Thus, it must be used to treat patients with venous ulcers. High compression must be used only in patients without arterial commitment. Lack of use of compression hosiery is associated to ulcer relapse. The study results do not permit conclusions about the best topical treatment for venous ulcer either.

Studies varied in terms of designs and used various products. In most studies, the sample was not calculated and the size, generally small, did not permit statistical tests. Several outcomes were evaluated in the same study and different ones between studies. Follow-up and treatment evaluation times were short, generally varying from days to weeks. Several studies presented limitations, such as the lack of explanation about the application method of the compression system or topical treatment, as well as the professional responsible for the procedure, lack of data related to the study site and patients' characteristics.

More randomized and controlled clinical trials need to be performed, with a priori determined samples, based on the primary outcome and with objective result measures, preferably evaluating only one main outcome.

\section{ACKNOWLEDGEMENTS}

We are grateful for the financial support granted by the Coordination for the Improvement of Higher Education Personnel (CAPES), to the Institutional Qualification Program (PQI) and to the State of São Paulo Research Foundation (FAPESP) for the resources granted to disseminate the study results at an international event - Sigma Theta Tau International 38th Biennial Convention - Indianapolis, Indiana USA, 2005.

\section{REFERENCES}

1. Johnson JJ, Paustrian C. Guideline for management of wounds in patients with lower-extremity venous disease. Glenview: Wound Ostomy and Continence Nurses Society - WOCN; 2005. 2. Doughty DB, Waldrop J, Ramundo J. Lower-extremity ulcers of vascular etiology. In: Bryant RA. Acute \& chronic wounds: nursing management. 2ed. St. Louis: Mosby; 2000. p.265-300.

3. Wipke-Tevis DD, Rantz MJ, Mehr DR, Popejoy L, Petroski G, Madsen R et al. Prevalence, incidence, management, and predictors of venous ulcers in the long-term-care population using the MDS. Adv Skin Wound Care 2000; 13(5):218-24.
4. Cornwall JV, Doré CJ, Lewis JD. Leg ulcers: epidemiology and aetiology. Br J Surg 1986; 73(9):693-6.

5. Maffei FHA, Magaldi C, Pinho SZ. Varicose veins and chronic venous insufficiency in Brasil: prevalence among 1755 inhabitants of a country town. J Epidemiol 1986; 15:207-10. 6. Toro AG. Enfermería basada en la evidencia: como incorporar la investigación a la práctica de los cuidados. Granada: Fundación Index; 2001.

7. Stetler CB, Morsi D, Rucki S, Broughton S, Corrigan B, Fitzgerald $\mathrm{J}$ et al. Utilization-focused integrative reviews in a nursing service. Appl Nurs Res 1998; 11(4):195-206.

8. Polit DF, Hungler BP. Nursing research. Principles and methods. 6ed. Philadelphia: Lippincott; 1999. 
9. Guyatt HG, Sackett DL, Cook DJ. Users' guides to the medical literature. II. How to use an article about therapy or prevention. JAMA 1993; 270:2598-601.

10. Galvão CM, Sawada NO, Trevizan MA. Revisão sistemática: recurso que proporciona a incorporação das evidências na prática da enfermagem. Rev Latino-am Enfermagem 2004; 12(3):549-56.

11. Cullum N, Nelson EA, Fletcher AW, Sheldon TA. Compression for venous leg ulcers. Cochrane Database Syst. $2003 ; 1$.

12. Nelson EA, Bell-Syer SEM, Cullum NA. Compression for preventing recurrence of venous ulcers. Cochrane Library. $2003 ; 1$.

13. Danielsen L, Madsen SM, Henriksen L, Sindrup J, Petersen LJ. Subbandage pressure measurements comparing a longstretch with a short-stretch compression bandage. Acta Dermatol Venereol. 1998; 78(3):201-4.

14. McCulloch JM, Marler KC, Neal MB, Phifer TJ. Intermittent pneumatic compression improves venous ulcer healing. Adv Wound Care 1994; 7(4):22-6.

15. Scriven JM, Bello M, Taylor LE, Wood AJ, London NJ. Studies of a new multi-layer compression bandage for the treatment of venous ulceration. J Wound Care. 2000; $9(3): 143-7$.

16. Wilkinson E, Buttfield S, Cooper S, Young E. Trial of two bandaging systems for chronic venous leg ulcers. J Wound Care. 1997; 6(7):339-40.

17. Zamboni P, Cisno C, Marchetti F, Mazza P, Fogato L, Carandina $S$, et al. Minimally invasive surgical management of primary venous ulcers vs. compression treatment: a randomized clinical trial. Eur J Vasc Endovasc Surg. 2003; 25(4):313-8.

18. Stancey MC, Joop-Mckay AG, Rashid P, Hoskin E, Thompson $\mathrm{PJ}$. The influence of dressings on venous ulcer healing: a randomized trial. Eur J Vasc Endovasc Surg 1997; 13(2):174-9.

19. Belcaro GV, Nicolaides AN. Acute effects of intermittent sequential compression in venous hypertension. J Cardiovasc Surg. 1993; 34(6):493-7.

20. Santilli SM, Valusek PA, Robinson C. Use of a noncontact radiant heat bandage for the treatment of chronic venous stasis ulcer. Adv Wound Care 1999; 12(2):89-93.

21. Partsch $H$, Menzinger $G$, Mostbeck $A$. Inelastic leg compression is more effective to reduce deep venous refluxes than elastic bandages. Dermatol Surg. 1999; 25(9):695700 .

22. Scriven JM, Taylor LE, Wood AJ, Bell PRF, Naylor AR, London NJ. A prospective randomized trial of four-layer versus short stretch compression bandages for the treatment of venous leg ulcers. Ann R Coll Surg Engl 1998; 80(3):21520

23. Veraart JCJM, Pronk G, Neumann MA. Pressure differences of elastic compression stockings at ankle region. Dermatol Surg 1997; 23(10):935-9.

24. Guest M, Smith J], Sira MS, Madden P, Greenhalgh RM, Davies $\mathrm{H}$. Venous ulcer healing by four-layer compression bandaging is not influenced by the pattern of venous incompetence. Br J Surg 1999; 86(11):1437-40.
25. Marston WA, Carlin RE, Passman MA, Farber MA, Keagy BA. Healing rates and cost efficacy of outpatient treatment for leg ulcer associated with venous insufficiency. J Vasc Surg 1999; 30(3):491-8.

26. Thomson B, Hooper P, Powell R, Warin AP. Four-layer bandaging and healing rates of venous leg ulcers. J Wound Care 1996; 5(5):213-6.

27. Vowden KR, Wilkinson $D$, Vowden P. The k-four bandage system: evaluating its effectiveness on recalcitrant venous leg ulcers. J Wound Care 2001; 10(5):182-4.

28. Hofman D, Cherry GW. The use of short: stretch bandaging to control oedema. J Wound Care. 1998; 7(1):10-2.

29. Hofman D. Intermittent compression treatment for venous leg ulcers. J Wound Care. 1995; 4(4):163-5.

30. Armstrong SH, Ruckley CV. Use of a fibrous dressing in exuding leg ulcers. J Wound Care 1997; 6(7):322-4

31. Andersen KE, Franken CPM, Gad P, Larsen AM, Larsen JR, Van Neer PAF et al. A randomized, controlled study to compare the effectiveness of two foam dressings in the management of lower leg ulcers. Ostomy Wound Manage 2002; 48(8):34-41

32. Limova M, Troyer-Caudle J. Controlled, randomized clinical trial of 2 hydrocolloid dressings in the management of venous insufficiency ulcers. J Vasc Nurs 2002; 20(1):22-32.

33. Bowszyc J, Silny W, Browszyc-Dmochoska M, Kazmierowski M, Ben-Amer HM, Garbowska T, Harding E. Comparison of two dressings in the treatment of venous leg ulcer. J Wound Care 1995; 4(3):106-10.

34. Arnold ET, Stanley JC, Fellows EP, Moncada GA, Allen R, Hutchinson $\mathrm{J}$ J et al. Prospective, multicenter study of imaging lower extremity venous ulcer. Ann Vasc Surg 1994; 8(4):356-62.

35. Harding KG, Price P, Robinson B, Thomas S, Hofman D. Cost and dressing evaluation of hydrofiber and alginate dressings in the management of community-based patients with chronic leg ulceration. Wounds 2001; 13(6):229-36. 36. Peschen M, Weichenthal M, Schöpf E, Vanscheidt W. Lowfrequency ultrasound treatment of chronic venous leg ulcer in an outpatient therapy. Acta Dermatol Venereol 1997; 77(4):311-4

37. Franek $A$, Król P, Kucharzewski M. Does low output laser stimulation enhance the healing of crural ulceration? Some critical remarks. Med Engineering \& Physics 2002; 24(9):607-15.

38. Teep RGC, Roseeuw DI, Hermans J, Koebrugge EJ, Altena $\mathrm{T}$, Coninck $\mathrm{A}$ et al. Randomized trial comparing cryopreserved cultured epidermal allografts with hydrocolloid dressings in healing chronic venous ulcers. J Am Acad Dermatol 1993; 29(6): $982-8$

39. Bishop JB, Phillips LG, Mustoe TA, Vander Zee AJ, Wiersema $L$, Roach DE et al. A prospective randomized evaluator-blinded trial of two potential wound healing agents for the treatment of venous stasis ulcers. J Vasc Surg 1993; $16(2): 251-7$

40. Incandela L, Belcaro G, Cesarone MR, De Sanctis MT, Griffin M Microangiopathy and venous ulceration: topical treatment with essaven gel. A placebo-controlled, randomized study. Angiology 2001; 52(Suppl 3):s17-21. 
41. Incandela L, Belcaro G, Cesarone MR, De Sanctis MT, Griffin M. Changes in microcirculation in venous ulcer with essaven gel: a pilot, cross-over, placebo-controlled, randomized study. Angiology 2001; 52(Suppl 3):s23-7.

42. Pardes JB, Carson PA, Eaglstein WH, Falanga V. Mupirocin treatment of exudative venous ulcers. J Am Acad Dermatol $1993 ; 29(3): 497-8$.

43. De Sanctis MT, Incandela L, Belcaro G, Cesarone, MR. Topical treatment of venous microangiopathy in patients with venous ulceration with essaven gel: a placebo-controlled, randomized study. Angiology 2001; 52(Suppl 3):s529-34.

44. Piérard-Franchimont $C$, Paquet $P$, Arrese JE, Piérard GE. Healing rate and bacterial necrotizing in venous leg ulcers. Dermatology 1997; 194(4):383-7.

45. Ennis WJ, Meneses P. ${ }^{31} \mathrm{P}$ NMR spectroscopic analysis of wound healing: the effect of hydrocolloid therapy. Adv Wound Care $1996 ; 9(3): 21-6$. 